\title{
Secondary mineral formation associated with respiration of nontronite, NAu-1 by iron reducing bacteria
}

\author{
S. Erin O'Reilly, Janet Watkins, and Yoko Furukawa ${ }^{\text {a) }}$ \\ Naval Research Laboratory, Seafloor Sciences Branch, Stennis Space Center, Mississippi 39529
}

(Received 10 May 2005; accepted 30 August 2005; published 24 October 2005)

\begin{abstract}
Experimental batch and miscible-flow cultures were studied in order to determine the mechanistic pathways of microbial $\mathrm{Fe}(\mathrm{III})$ respiration in ferruginous smectite clay, NAu-1. The primary purpose was to resolve if alteration of smectite and release of Fe precedes microbial respiration. Alteration of NAu-1, represented by the morphological and mineralogical changes, occurred regardless of the extent of microbial $\mathrm{Fe}(\mathrm{III})$ reduction in all of our experimental systems, including those that contained heat-killed bacteria and those in which $\mathrm{O}_{2}$, rather than $\mathrm{Fe}(\mathrm{III})$, was the primary terminal electron acceptor. The solid alteration products observed under transmission electron microscopy included poorly crystalline smectite with diffuse electron diffraction signals, discrete grains of $\mathrm{Fe}$-free amorphous aluminosilicate with increased $\mathrm{Al} / \mathrm{Si}$ ratio, Fe-rich grains, and amorphous $\mathrm{Si}$ globules in the immediate vicinity of bacterial cells and extracellular polymeric substances. In reducing systems, $\mathrm{Fe}$ was also found as siderite. The small amount of $\mathrm{Fe}$ partitioned to the aqueous phase was primarily in the form of dissolved $\mathrm{Fe}$ (III) species even in the systems in which $\mathrm{Fe}(\mathrm{III})$ was the primary terminal electron acceptor for microbial respiration. From these observations, we conclude that microbial respiration of $\mathrm{Fe}(\mathrm{III})$ in our laboratory systems proceeded through the following: (1) alteration of NAu-1 and concurrent release of Fe(III) from the octahedral sheets of NAu-1; and (2) subsequent microbial respiration of Fe(III). () 2005 American Institute of Physics. [DOI: $10.1063 / 1.2084787$ ]
\end{abstract}

\section{INTRODUCTION}

Mechanistic pathways of microbial iron reduction in clay minerals are of great interest to sedimentary biogeochemists as $\mathrm{Fe}(\mathrm{III})$ minerals are major terminal electron acceptors (TEA) for organic matter (OM) remineralization in a wide range of sedimentary environments. ${ }^{1-5}$ The pathways are also of interest to soil scientists: Fe(III) reduction in crystalline clay minerals causes fundamental changes to the physicochemical properties of soil clays such as swellability, exchange capacity, and flocculation properties, affecting their characteristics in agricultural and contaminant dynamics contexts. ${ }^{6,7}$

It has been considered that more $\mathrm{Fe}(\mathrm{III})$ is subject to reduction by inorganic reducing agents, such as aqueous sulfides, than to reduction by microbial respiration in typical marine sediments. ${ }^{8,9}$ The formation of crystalline iron sulfides such as pyrite in deep sea, margin, and shelf sediments has been reported to be dominated by abiotic reactions between microbially reduced aqueous sulfides and $\mathrm{Fe}(\mathrm{III})$ bound to detrital minerals. ${ }^{10}$ Recent studies in salt marsh environments, however, highlight the quantitative significance of $\mathrm{Fe}(\mathrm{III})$ reduction by microbial respiration in sediments with high reworking rates. ${ }^{5,11,12}$ In these environments, more than $50 \%$ of the OM remineralization can be attributed to $\mathrm{Fe}(\mathrm{III})$ minerals as TEA. ${ }^{13}$

Until recently, microbial $\mathrm{Fe}(\mathrm{III})$ reduction in sediments was believed to be limited to the respiration of $\mathrm{Fe}(\mathrm{III})$ in poorly crystalline iron (oxy)hydroxides such as nanogoethite

\footnotetext{
${ }^{a)}$ Author to whom correspondence should be addressed; electronic mail: yoko.furukawa@nrlssc.navy.mil
}

and ferrihydrite ${ }^{14}$ However, several laboratory studies have suggested that $\mathrm{Fe}(\mathrm{III})$ contained in the octahedral sheets of ferruginous smectite clays could also be available for microbial respiration by dissimilatory iron reducing bacteria (DIRB). ${ }^{6,15,16}$ The hypothesis, that DIRB may be able to respire structural $\mathrm{Fe}(\mathrm{III})$ in ferruginous clays, then prompted recent studies on interactions between DIRB and ferruginous clay minerals. ${ }^{17-23}$

Despite the abundance of recent experimental studies, the mechanisms of interactions between DIRB and ferruginous clays are not well understood. Past studies of DIRB-Fe oxides interactions have suggested that direct contact between Fe oxide surfaces and bacterial cells is required, or at least highly desirable. ${ }^{24-28}$ However, bacterial cells interacting with ferruginous smectite can only be in direct contact with $\mathrm{Fe}$ atoms at the sheet edges of or within defect sites of the clay mineral because $\mathrm{Fe}$ in ferruginous smectite is predominantly located in the octahedral sheets that are shielded from the surface by the tetrahedral sheets. ${ }^{29}$ Thus, if microbial $\mathrm{Fe}(\mathrm{III})$ respiration was to proceed via a solid-state transformation of $\mathrm{Fe}(\mathrm{III})$ to $\mathrm{Fe}(\mathrm{II})$, it would require a solid-state transfer of electrons across tetrahedral sheets. Alternatively, reduction may also occur at the sheet edges where electrons may be transferred along an octahedral sheet to where it is terminated and exposed. Possible mechanisms for such electron transfer processes are still under debate. ${ }^{30}$

Existing studies specific to DIRB-smectite interactions have focused on the relationship between microbial activities and the extent of $\mathrm{Fe}$ reduction, ${ }^{6,21}$ microbial growth, ${ }^{20}$ and changes to the bulk physicochemical properties of clays. ${ }^{22}$ Little attention has been given to the mineralogical evolu- 
tions that occur during and as a result of DIRB-clay interactions. A recent study identified some of the secondary minerals recovered at the end of incubations (i.e., biogenic smectite with increased interlayer cations, vivianite). ${ }^{17}$ However, the phases reported were not exhaustive, for example, as Al-rich solid phases, expected from the observed nonstoichiometric aqueous release of $\mathrm{Si}, \mathrm{Al}$, and $\mathrm{Fe}$, were not shown. In addition, the report was limited to anaerobic systems with or without viable DIRB. More systematic mineralogical descriptions would be desired if mechanistic pathways are to be discussed based on mineralogy. Consequently, the focus of this study is to investigate the alteration of ferruginous smectite in systems with active DIRB-clay interactions with and without $\mathrm{O}_{2}$ as the TEA, and to discuss mechanistic pathways that yielded the observed secondary mineral assemblages.

\section{LABORATORY EXPERIMENTS}

In order to examine the mechanisms of DIRB and ferruginous clay interactions, we conducted two sets of laboratory experiments. The first set (Experiment 1) was a flowthrough experiment using a miscible-type flow-through reactor in which the extent of $\mathrm{Fe}(\mathrm{III})$ reduction in solids was determined at the end of seven days, and solid phases were investigated using transmission electron microscopy (TEM). The second set (Experiment 2) was a series of batch incubation experiments in which the viability of DIRB and availability of $\mathrm{O}_{2}$ as the primary TEA were varied. The extent of $\mathrm{Fe}$ (III) reduction was determined for each incubation culture, and solid products were analyzed for secondary mineralogy using TEM. In this manuscript, we focus on the link between the extent of microbial Fe(III) reduction and mineralogical changes, and discuss mechanistic pathways that are responsible for the changes.

\section{Materials}

Nontronite NAu-1 (Clay Minerals Society Source Clays Repository) is a ferruginous $\left(4.50 \mathrm{mmol} \mathrm{Fe} \mathrm{g}^{-1}\right)$ smectite from the Uley Graphite Mine in Australia. ${ }^{31}$ It was ground, size-fractioned, and freeze dried prior to use. Only the $<0.2 \mu \mathrm{m}$ fraction was used for the experiments reported here, ensuring $>99 \%$ purity. ${ }^{31}$ Prior to each experiment, a required amount of size-fractionated NAu-1 was sterilized by microwave radiation, and sterility was confirmed with the lack of bacterial growth in Luria-Bertani (LB) agar after 24 hours.

A minimal culture medium (i.e., M1 medium), adapted from Myers and Nealson, ${ }^{32}$ was used in our experiments. This medium has a chemical composition (Table II) that is better defined than other culture media commonly used with S. oneidensis such as LB medium. It was specifically developed for the cultivation of S. oneidensis, ${ }^{33}$ and has been successfully employed by the previous studies of ferruginous clay-S. oneidensis incubations. ${ }^{6,17,21,22}$ For experiments reported here, M1 was diluted to $25 \%$ because full strength media was not necessary for flow studies, which constantly supply fresh media, and batch studies were designed analogous to flow studies.
S. oneidensis bacteria strain MR-1 is a facultative anaerobe capable of dissimilatory iron reduction in anaerobic environments. ${ }^{32}$ Prior to each experiment, the bacteria, cultured aerobically in LB media, were diluted into fresh LB media and cultured under continuous $200 \mathrm{rpm}$ shaking at room temperature to a concentration of 1.8 $\times 10^{8}$ cells $\mathrm{mL}^{-1}$. Cultures for Experiment 2 (batch systems) were washed twice and resuspended in 25\% M1 before the start of each experiment. LB suspensions were used directly when loading Experiment 1 (miscible-flow systems), but the bacteria were washed free of LB using 25\% M1 during the experimental set up prior to each run. For runs lacking viable bacteria, the bacterial suspension was heat killed using microwave radiation prior to the start of the experiment. Sterility was confirmed by lack of growth on LB agar. For experiments with no bacterial cells and no associated biomolecules in Experiment 2, sterile, bacteria-free 25\% M1 was used.

\section{Experiment 1}

In the flow-through experimental run, NAu-1 $(200 \mathrm{mg}$ dry weight) and $S$. oneidensis cells were loaded into a 25 -mm-diameter plug-flow reactor supported by a $0.2 \mu \mathrm{m}$ membrane filter (polyethersulfone membrane), and subsequently exposed to a flow of $\mathrm{O}_{2}$-free $25 \% \mathrm{M} 1$ media (including $5 \mathrm{mM}$ lactate) at a flow rate of $0.3 \mathrm{ml} \mathrm{min}^{-1}$. Effluent solutions were pooled into separate aliquots every $40 \mathrm{~min}$ for analysis. The entire flow system was enclosed in an anaerobic chamber to ensure that $\mathrm{Fe}$ (III) in NAu-1 was the only TEA for S. oneidensis. After seven days, the reactor was opened, and solid products were stored in an $\mathrm{O}_{2}$-free environment until later analysis of reduced $\mathrm{Fe}$ as described below. Viability of DIRB in the solid products was confirmed by culturing. The aliquots of effluent solutions were analyzed for dissolved metal concentrations using inductively coupled plasma atomic emission spectroscopy (ICP).

\section{Experiment 2}

Forty milligrams of NAu-1 was added to sterile polypropylene centrifuge tubes and microwave sterilized. Ten milliliters of $25 \% \mathrm{M} 1$ with $5 \mathrm{mM}$ lactate ( \pm bacterial suspension) was then added. Anaerobic, live culture systems and a series of control systems were prepared that included the following: (1) anaerobic systems with viable bacteria; (2) anaerobic systems with heat killed bacteria; and (3) aerobic systems with viable bacteria. For each experimental setting, three to four tubes were sacrificed at 4, 24, 48, and $168 \mathrm{~h}$ for solid and solution analyses as follows. Each tube was centrifuged at $4500 \mathrm{rpm}$ for $10 \mathrm{~min}$, and $7 \mathrm{ml}$ of the supernatant was removed, filtered, and analyzed for dissolved metal concentrations using ICP and spectrophotometry. After $\mathrm{pH}$ analysis with a microelectrode or combination electrode, the remainder of the sample was saved to determine the extent of Fe reduction as described in the following section. Samples for transmission electron microscopy (TEM) analysis were collected and prepared as described in the later section. Time series bacterial population counts for anaerobic batches with viable bacteria were estimated using SYBR Green I fluorescent microscopy ${ }^{34}$ using a subsample from each run duration; 


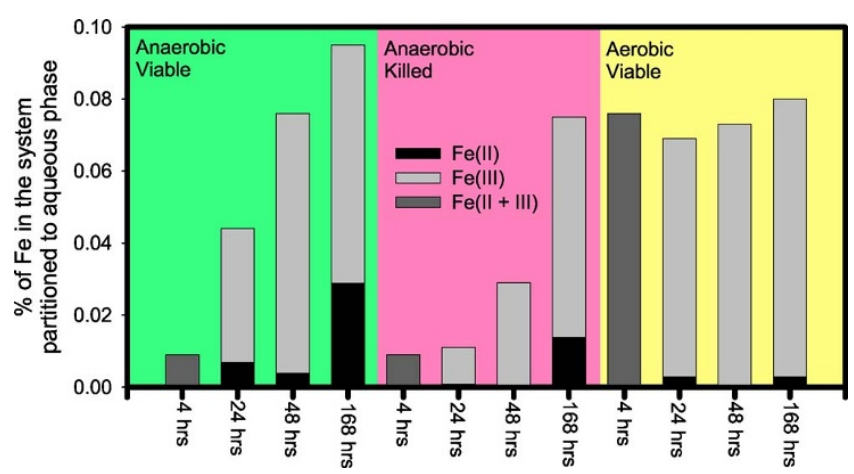

FIG. 1. (Color) The percentage of Fe in each system of Experiment 2 that was partitioned to the aqueous phases. For some of the runs, the $\mathrm{Fe}(\mathrm{II}) / \mathrm{Fe}$ (III) ratio of aqueous $\mathrm{Fe}$ were determined by ferrozine assay, and are reported here. Note that the aqueous partitioning of Fe was extremely small $(<0.1 \%$ of total $\mathrm{Fe}$ in the system).

the counts yielded $1.4 \times 10^{8}$ cells $\mathrm{ml}^{-1}$ at time zero and 1.2 $\times 10^{8}, 1.1 \times 10^{8}, 8.4 \times 10^{8}$, and $1.4 \times 10^{8}$ cells $\mathrm{ml}^{-1}$ at 4,24 , 48, and $168 \mathrm{~h}$, respectively. These values indicate that bacteria remained viable for the duration of anaerobic batch experiments inoculated with viable bacteria.

\section{$\mathrm{Fe}(\mathrm{II})$ and $\mathrm{Fe}(\mathrm{III})$ analysis for solutions}

The concentrations of dissolved Fe(II) and Fe(III) species in supernatant solutions from Experiment 2 (i.e., batch experiments) were determined by the ferrozine procedure using the spectrophotometric analytical protocol described by Viollier and co-workers which utilizes dissolved Fe(III) solutions and their reduced products after the addition of hydroxylamine hydrochloride as standards. ${ }^{35}$ The interpretation of spectrophotometry readings was conducted according to the updated procedure described by Washington and co-workers. ${ }^{36}$ In addition, total dissolved Fe [i.e., aqueous $\mathrm{Fe}(\mathrm{II})+\mathrm{Fe}(\mathrm{III})]$ concentrations were determined by ICP for the effluent solution aliquots from Experiment 1 (i.e., flowthrough experiment) and supernatant solutions from Experiment 2 (i.e., batch experiments). It should be noted that the concentration of total dissolved $\mathrm{Fe}$ in each pool of effluent solutions of Experiment 1 (i.e., flow-through experiment) was very small $\left(<2 \mu\right.$ moles $\left.1^{-1}\right]$ and thus the relative concentrations of dissolved $\mathrm{Fe}(\mathrm{II})$ and $\mathrm{Fe}(\mathrm{III})$ were not determined with the ferrozine procedure for Experiment 1.

\section{Total Fe(II) analysis}

The extent of Fe reduction was determined by the sum of solid-phase $\mathrm{Fe}$ (II) (via 60 min $0.5 \mathrm{~N} \mathrm{HCl}$ extraction followed by the ferrozine assay $\left.{ }^{17,37}\right]$ and $\mathrm{Fe}$ (II) in aqueous phase (as determined above). In reality, the quantity of dissolved $\mathrm{Fe}(\mathrm{II})$ in aqueous phase was negligible (i.e., < $<1 \%$ ] compared to the quantity of solid-phase $\mathrm{Fe}(\mathrm{II})$ in all of the reducing systems. It should be noted that crystalline silicates, including NAu-1, do not completely dissolve in $0.5 \mathrm{~N} \mathrm{HCl}$, and thus this $\mathrm{Fe}(\mathrm{II})$ extraction method through partial digestion is valid only when $\mathrm{Fe}(\mathrm{II})$ is exclusively associated with nonsilicates (e.g., carbonates, surface sorbed species) and poorly crystallized clays. However, the method has been shown to fully extract solid-phase $\mathrm{Fe}(\mathrm{II})$ resulting from the microbial reduction of

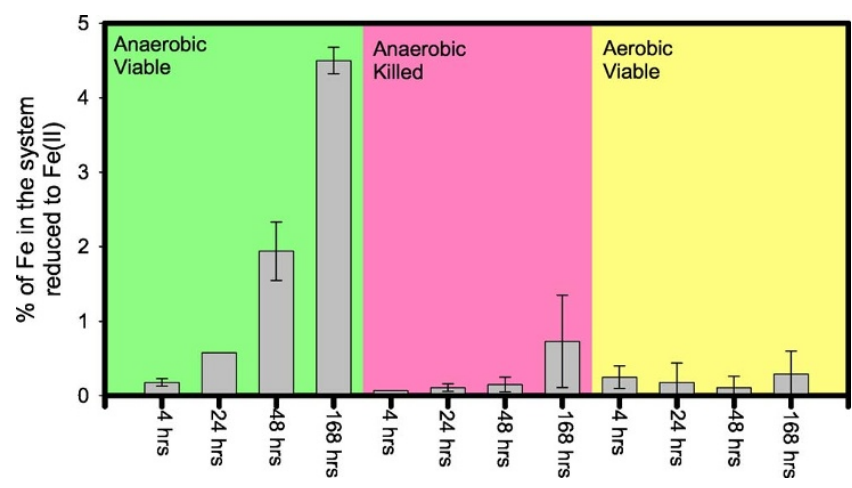

FIG. 2. (Color) The percentage of Fe in each system of Experiment 2 that was in the reduced Fe(II) form. Note that most of the Fe(II) was partitioned into the solid phases. The mean and standard deviation of duplicate runs under each condition are shown.

ferruginous smectite clays in laboratory cultures similar to our experimental cultures, as a good agreement was previously confirmed between $\mathrm{Fe}(\mathrm{II})$ extracted by $0.5 \mathrm{HCl}$, Fe(II) quantified by the solid-state Mössbauer spectroscopy, and $\mathrm{Fe}(\mathrm{II})$ quantified following the whole-clay digestion by $\mathrm{HF}$ $+\mathrm{H}_{2} \mathrm{SO}_{4}{ }^{6}$

The percentage of Fe reduced in each sample was determined by the comparison between (A) HCl-extracted $\mathrm{Fe}$ (II) plus $\mathrm{Fe}$ (II) in the supernatant and (B) total Fe of the starting mixture which includes Fe in NAu-1 (i.e., $4.50 \mathrm{mmol} F e$ per each gram of NAu-1 as previously reported $\left.{ }^{31}\right]$ and $\mathrm{Fe}$ in the 25\% M1 media.

For Experiment 1 (i.e., flow-through experiment), solids on the reactor filter paper were dried, weighed, and added to a test tube preloaded with $10 \mathrm{ml}$ of $0.5 \mathrm{~N} \mathrm{HCl}$. The test tube was capped and vortexed immediately. All of these steps were conducted inside the anaerobic chamber. One hour after the addition of the solids into the $0.5 \mathrm{~N} \mathrm{HCl}$, the test tube was removed from the anaerobic chamber, and an aliquot of the extract solution was analyzed for $\mathrm{HCl}$-extracted $\mathrm{Fe}$ (II) using ferrozine assay. ${ }^{17,37}$

After the removal of $7 \mathrm{ml}$ supernatant solution for ICP analysis, each sample from Experiment 2 (i.e., batch experiments) contained $3 \mathrm{ml}$ of solution in addition to the solids. Seventeen milliliters of $0.6 \mathrm{~N} \mathrm{HCl}$ was added to this mixture for $1 \mathrm{~h}$ digestion, followed by the ferrozine assay. The ferrozine assay in this case determined the sum of $\mathrm{Fe}(\mathrm{II})$ extracted from solids and $\mathrm{Fe}(\mathrm{II})$ that existed in the remaining $3 \mathrm{ml}$ of aqueous phase. Consequently, a correction was made to account for the aqueous $\mathrm{Fe}(\mathrm{II})$ removed along with the $7 \mathrm{ml}$ ICP subsample, by using the aqueous Fe(II) concentrations determined by the ferrozine assay.

\section{TEM analysis}

Samples were prepared for TEM analysis from Experiment 2 (i.e., batch experiments) as follows. After centrifugation, a $5 \mu \mathrm{l}$ aliquot of the mixture of aqueous solution and solid suspension was transferred to a BEEM capsule filled with prepared Nanoplast resin using a pipette. Nanoplast is a hydrophilic resin that has been successfully used to prepare aqueous suspensions of organoclay complexes for TEM ultrathin section preparations. ${ }^{38-41}$ It has become the embed- 


\begin{tabular}{|c|c|c|c|c|c|c|c|c|c|c|c|c|c|c|c|c|c|}
\hline \multirow[b]{2}{*}{$\begin{array}{c}\text { Sample } \\
\text { ID }\end{array}$} & \multicolumn{6}{|c|}{ Initial Conditions } & \multicolumn{6}{|c|}{ Auqueous phase Fe results } & \multicolumn{3}{|c|}{ Solid Fe extraction results } & \multicolumn{2}{|c|}{ Fe reduction } \\
\hline & Description & $\begin{array}{l}\text { Run } \\
\text { (hrs) }\end{array}$ & $\begin{array}{c}\text { Total } \\
\text { NAu-1 in } \\
\text { system } \\
(\mathrm{g})\end{array}$ & $\begin{array}{c}\mathrm{Fe}(\mathrm{III}) \\
(\mathrm{mols}) \text { in } \\
\text { initial NAu-1 }\end{array}$ & $\begin{array}{l}\text { Aqueous } \\
\text { culture media } \\
(25 \% \mathrm{M} 1) \\
(\mathrm{ml})\end{array}$ & $\begin{array}{c}\mathrm{Fe}(\text { total) } \\
\text { (mols) in initial } \\
\text { aqueous } \\
\text { culture media }\end{array}$ & $\begin{array}{c}\text { Total } \\
\mathrm{Fe}(\mathrm{aq}) \text { in } \\
\text { media }^{\mathrm{a}}(\mathrm{M})\end{array}$ & $\begin{array}{l}\% \text { Fe in system } \\
\text { partitioned to } \\
\text { aqueous phase }\end{array}$ & $\begin{array}{l}\mathrm{Fe}(\mathrm{II}) \text { in } \\
\text { media }^{\mathrm{b}} \\
(\mathrm{M})\end{array}$ & $\begin{array}{c}\mathrm{Fe}(\mathrm{II})+ \\
\mathrm{Fe}(\mathrm{III}) \text { in } \\
\text { media }^{\mathrm{b}}(\mathrm{M})\end{array}$ & $\begin{array}{c}\mathrm{Fe}(\mathrm{III}) \text { in } \\
\text { media by } \\
\text { difference } \\
\text { (M) }\end{array}$ & $\begin{array}{c}\mathrm{Fe}(\mathrm{II}) \text { in } \\
\text { aqueous } \\
\text { media } \\
(\mathrm{mols})\end{array}$ & $\begin{array}{l}\text { Extraction } \\
\text { fluid } \\
\text { volume }^{\mathrm{c}} \\
(\mathrm{ml})\end{array}$ & $\begin{array}{l}\mathrm{Fe}(\mathrm{II}) \text { in } \\
\text { extraction } \\
\text { fluid (M) }\end{array}$ & $\begin{array}{c}\mathrm{Fe}(\mathrm{II}) \text { in } \\
\text { extraction } \\
\text { fluid (mols) }\end{array}$ & $\begin{array}{l}\text { Total reduced } \\
\mathrm{Fe}(\mathrm{III})^{\mathrm{d}} \\
\text { (micromols) }^{\text {mats }}\end{array}$ & $\begin{array}{l}\% \mathrm{Fe} \\
\text { reduction }\end{array}$ \\
\hline 200 & Anoxic Live & 4 & 0.0403 & $1.81 \mathrm{E}-04$ & 10 & $1.35 \mathrm{E}-08$ & $1.68 \mathrm{E}-06$ & 0.0 & & & & & 20 & $1.96 \mathrm{E}-05$ & $3.92 \mathrm{E}-07$ & $3.92 \mathrm{E}-07$ & 0.2 \\
\hline 201 & Anoxic Live & 4 & 0.0401 & $1.80 \mathrm{E}-04$ & 10 & $1.35 \mathrm{E}-08$ & $1.45 \mathrm{E}-06$ & 0.0 & & & & & 20 & $1.32 \mathrm{E}-05$ & $2.63 \mathrm{E}-07$ & 2.63E- -07 & 01 \\
\hline 202 & Anoxic Live & 4 & 0.0401 & $1.80 \mathrm{E}-04$ & 10 & $1.35 \mathrm{E}-08$ & $1.51 \mathrm{E}-06$ & 0.0 & & & & & 20 & & & & \\
\hline 203 & Anoxic Live & 4 & 0.0402 & $1.81 \mathrm{E}-04$ & 10 & $1.35 \mathrm{E}-08$ & $1.75 \mathrm{E}-06$ & 0.0 & & & & & 20 & & & & \\
\hline 204 & Anoxic Live & 24 & 0.0401 & $1.80 \mathrm{E}-04$ & 10 & $1.35 \mathrm{E}-08$ & $5.72 \mathrm{E}-06$ & 0.0 & $6.00 \mathrm{E}-07$ & $3.68 \mathrm{E}-06$ & $3.08 \mathrm{E}-06$ & $6.00 \mathrm{E}-09$ & 20 & $5.19 \mathrm{E}-05$ & $1.04 \mathrm{E}-06$ & $1.04 \mathrm{E}-06$ & 0.6 \\
\hline 205 & Anoxic Live & 24 & 0.0402 & $1.81 \mathrm{E}-04$ & 10 & $1.35 \mathrm{E}-08$ & $8.98 \mathrm{E}-06$ & 0.0 & & & & & 20 & $5.19 \mathrm{E}-05$ & $1.04 \mathrm{E}-06$ & $1.04 \mathrm{E}-06$ & 0.6 \\
\hline 206 & Anoxic Live & 24 & 0.0402 & $1.81 \mathrm{E}-04$ & 10 & $1.35 \mathrm{E}-08$ & $8.44 \mathrm{E}-06$ & 0.0 & & & & & 20 & & & & \\
\hline 207 & Anoxic Live & 24 & 0.0400 & $1.80 \mathrm{E}-04$ & 10 & $1.35 \mathrm{E}-08$ & $8.52 \mathrm{E}-06$ & 0.0 & & & & & 20 & & & & \\
\hline 208 & Anoxic Live & 48 & 0.0399 & $1.80 \mathrm{E}-04$ & 10 & $1.35 \mathrm{E}-08$ & $1.31 \mathrm{E}-05$ & 0.1 & $8.00 \mathrm{E}-07$ & $1.62 \mathrm{E}-05$ & $1.54 \mathrm{E}-05$ & $8.00 \mathrm{E}-09$ & 20 & $1.49 \mathrm{E}-04$ & $2.97 \mathrm{E}-06$ & $2.98 \mathrm{E}-06$ & 17 \\
\hline 209 & Anoxic Live & 48 & 0.0402 & $1.81 \mathrm{E}-04$ & 10 & $1.35 \mathrm{E}-08$ & $1.41 \mathrm{E}-05$ & 0.1 & & & & & 20 & $2.00 \mathrm{E}-04$ & $4.00 \mathrm{E}-06$ & $4.00 \mathrm{E}-06$ & 2.2 \\
\hline 210 & Anoxic Live & 48 & 0.0400 & $1.80 \mathrm{E}-04$ & 10 & $1.35 \mathrm{E}-08$ & $1.36 \mathrm{E}-05$ & 0.1 & & & & & 20 & & & & \\
\hline 211 & Anoxic Live & 48 & 0.0400 & $1.80 \mathrm{E}-04$ & 10 & $1.35 \mathrm{E}-08$ & 1.37E-05 & 0.1 & & & & & 20 & & & & \\
\hline 212 & Anoxic Live & 168 & 0.0400 & $1.80 \mathrm{E}-04$ & 10 & $1.35 \mathrm{E}-08$ & $1.85 \mathrm{E}-05$ & 0.1 & $6.00 \mathrm{E}-07$ & $1.84 \mathrm{E}-05$ & $1.78 \mathrm{E}-05$ & $6.00 \mathrm{E}-09$ & 20 & $3.94 \mathrm{E}-04$ & $7.87 \mathrm{E}-06$ & $7.888 \mathrm{E}-06$ & 4.4 \\
\hline 213 & Anoxic Live & 168 & 0.0403 & $1.81 \mathrm{E}-04$ & 10 & $1.35 \mathrm{E}-08$ & $2.27 \mathrm{E}-05$ & 0.1 & & & & & 20 & $4.20 \mathrm{E}-04$ & $8.39 \mathrm{E}-06$ & 8.39E-06 & 4.6 \\
\hline 214 & Anoxic Live & 168 & 0.0399 & $1.80 \mathrm{E}-04$ & 10 & $1.35 \mathrm{E}-08$ & $2.02 \mathrm{E}-05$ & 0.1 & & & & & 20 & & & & \\
\hline 215 & Anoxic Live & 168 & 0.0400 & $1.80 \mathrm{E}-04$ & 10 & $1.35 \mathrm{E}-08$ & $7.10 \mathrm{E}-06$ & 0.0 & $7.90 \mathrm{E}-06$ & $1.35 \mathrm{E}-05$ & $5.59 \mathrm{E}-06$ & $7.90 \mathrm{E}-08$ & 20 & & & & \\
\hline 216 & Anoxic Killed & 4 & 0.0403 & $1.81 \mathrm{E}-04$ & 10 & $1.35 \mathrm{E}-08$ & $1.62 \mathrm{E}-06$ & 0.0 & & & & & 20 & $6.70 \mathrm{E}-06$ & $1.34 \mathrm{E}-07$ & $1.34 \mathrm{E}-07$ & 0.1 \\
\hline 217 & Anoxic Killed & 4 & 0.0403 & $1.81 \mathrm{E}-04$ & 10 & $1.35 \mathrm{E}-08$ & $1.63 \mathrm{E}-06$ & 0.0 & & & & & 20 & $6.70 \mathrm{E}-06$ & $1.34 \mathrm{E}-07$ & $1.34 \mathrm{E}-07$ & 0.1 \\
\hline 218 & Anoxic Killed & 4 & 0.0399 & $1.80 \mathrm{E}-04$ & 10 & $1.35 \mathrm{E}-08$ & $1.60 \mathrm{E}-06$ & 0.0 & & & & & 20 & & & & \\
\hline 219 & Anoxic Killed & 24 & 0.0401 & $1.80 \mathrm{E}-04$ & 10 & $1.35 \mathrm{E}-08$ & $1.80 \mathrm{E}-06$ & 0.0 & $\mathrm{BDL}^{\mathrm{e}}$ & $1.48 \mathrm{E}-06$ & $1.34 \mathrm{E}-06$ & BDL & 20 & $6.70 \mathrm{E}-06$ & $1.34 \mathrm{E}-07$ & $1.33 \mathrm{E}-07$ & 0.1 \\
\hline 220 & Anoxic Killed & 24 & 0.0402 & $1.81 \mathrm{E}-04$ & 10 & $1.35 \mathrm{E}-08$ & $1.79 \mathrm{E}-06$ & 0.0 & & & & & 20 & $1.32 \mathrm{E}-05$ & $2.63 \mathrm{E}-07$ & $2.63 \mathrm{E}-07$ & 0.1 \\
\hline 221 & Anoxic Killed & 24 & 0.0403 & $1.81 \mathrm{E}-04$ & 10 & $1.35 \mathrm{E}-08$ & $1.86 \mathrm{E}-06$ & 0.0 & & & & & 20 & & & & \\
\hline 222 & Anoxic Killed & 48 & 0.0402 & $1.81 \mathrm{E}-04$ & 10 & $1.35 \mathrm{E}-08$ & $2.41 \mathrm{E}-06$ & 0.0 & BDL & $1.42 \mathrm{E}-06$ & $1.42 \mathrm{E}-06$ & BDL & 20 & $6.70 \mathrm{E}-06$ & $1.34 \mathrm{E}-07$ & $1.34 \mathrm{E}-07$ & 0.1 \\
\hline 223 & Anoxic Killed & 48 & 0.0401 & $1.80 \mathrm{E}-04$ & 10 & $1.35 \mathrm{E}-08$ & $2.51 \mathrm{E}-06$ & 0.0 & & & & & 20 & $1.96 \mathrm{E}-05$ & $3.92 \mathrm{E}-07$ & $3.92 \mathrm{E}-07$ & 0.2 \\
\hline 224 & Anoxic Killed & 48 & 0.0400 & $1.80 \mathrm{E}-04$ & 10 & $1.35 \mathrm{E}-08$ & $2.47 \mathrm{E}-06$ & 0.0 & & & & & 20 & & & & \\
\hline 225 & Anoxic Killed & 168 & 0.0399 & $1.80 \mathrm{E}-04$ & 10 & $1.35 \mathrm{E}-08$ & $1.33 \mathrm{E}-05$ & 0.1 & $3.80 \mathrm{E}-06$ & $2.01 \mathrm{E}-05$ & 1.63E-05 & $3.80 \mathrm{E}-08$ & 20 & 1.03E-04 & $2.07 \mathrm{E}-06$ & $2.10 \mathrm{E}-06$ & 1.2 \\
\hline 226 & Anoxic Killed & 168 & 0.0400 & $1.80 \mathrm{E}-04$ & 10 & $1.35 \mathrm{E}-08$ & $8.71 \mathrm{E}-06$ & 0.0 & & & & & 20 & $2.61 \mathrm{E}-05$ & $5.21 \mathrm{E}-07$ & $5.21 \mathrm{E}-07$ & 0.3 \\
\hline 227 & Anoxic Killed & 168 & 0.0403 & $1.81 \mathrm{E}-04$ & 10 & $1.35 \mathrm{E}-08$ & $1.89 \mathrm{E}-05$ & 0.1 & & & & & 20 & & & & \\
\hline 228 & Oxic Live & 4 & 0.0401 & $1.80 \mathrm{E}-04$ & 10 & $1.35 \mathrm{E}-08$ & $1.32 \mathrm{E}-05$ & 0.1 & & & & & 20 & $3.25 \mathrm{E}-05$ & $6.50 \mathrm{E}-07$ & $6.50 \mathrm{E}-07$ & 0.4 \\
\hline 229 & Oxic Live & 4 & 0.0400 & $1.80 \mathrm{E}-04$ & 10 & $1.35 \mathrm{E}-08$ & $1.20 \mathrm{E}-05$ & 0.1 & & & & & 20 & $1.32 \mathrm{E}-05$ & $2.63 \mathrm{E}-07$ & $2.63 \mathrm{E}-07$ & 0.1 \\
\hline 230 & Oxic Live & 4 & 0.0402 & $1.81 \mathrm{E}-04$ & 10 & $1.35 \mathrm{E}-08$ & $1.27 \mathrm{E}-05$ & 0.1 & & & & & 20 & & & & \\
\hline 231 & Oxic Live & 24 & 0.0400 & $1.80 \mathrm{E}-04$ & 10 & $1.35 \mathrm{E}-08$ & $1.68 \mathrm{E}-05$ & 0.1 & $1.10 \mathrm{E}-06$ & $1.34 \mathrm{E}-05$ & $1.23 \mathrm{E}-05$ & $1.10 \mathrm{E}-08$ & 20 & $3.25 \mathrm{E}-05$ & $6.50 \mathrm{E}-07$ & $6.58 \mathrm{E}-07$ & 0.4 \\
\hline 232 & Oxic Live & 24 & 0.0402 & $1.81 \mathrm{E}-04$ & 10 & $1.35 \mathrm{E}-08$ & $1.54 \mathrm{E}-05$ & 0.1 & BDL & $1.59 \mathrm{E}-05$ & $1.59 \mathrm{E}-05$ & BDL & 20 & $2.50 \mathrm{E}-07$ & $5.00 \mathrm{E}-09$ & $5.00 \mathrm{E}-09$ & 0.0 \\
\hline 233 & Oxic Live & 24 & 0.0399 & $1.80 \mathrm{E}-04$ & 10 & $1.35 \mathrm{E}-08$ & $1.56 \mathrm{E}-05$ & 0.1 & & & & & 20 & & & & \\
\hline 234 & Oxic Live & 48 & 0.0399 & $1.80 \mathrm{E}-04$ & 10 & $1.35 \mathrm{E}-08$ & $1.75 \mathrm{E}-06$ & 0.0 & & & & & 20 & $2.50 \mathrm{E}-07$ & $5.00 \mathrm{E}-09$ & $5.00 \mathrm{E}-09$ & 0.0 \\
\hline 235 & Oxic Live & 48 & 0.0401 & $1.80 \mathrm{E}-04$ & 10 & $1.35 \mathrm{E}-08$ & $1.60 \mathrm{E}-05$ & 0.1 & BDL & $1.56 \mathrm{E}-05$ & $1.56 \mathrm{E}-05$ & BDL & 20 & $1.96 \mathrm{E}-05$ & $3.92 \mathrm{E}-07$ & $3.92 \mathrm{E}-07$ & 0.2 \\
\hline 236 & Oxic Live & 48 & 0.0399 & $1.80 \mathrm{E}-04$ & 10 & $1.35 \mathrm{E}-08$ & $1.59 \mathrm{E}-05$ & 0.1 & & & & & 20 & & & & \\
\hline 237 & Oxic Live & 168 & 0.0399 & $1.80 \mathrm{E}-04$ & 10 & $1.35 \mathrm{E}-08$ & $1.86 \mathrm{E}-05$ & 0.1 & $7.00 \mathrm{E}-07$ & $1.64 \mathrm{E}-05$ & $1.57 \mathrm{E}-05$ & $7.00 \mathrm{E}-09$ & 20 & $4.54 \mathrm{E}-05$ & $9.08 \mathrm{E}-07$ & $9.13 \mathrm{E}-07$ & 0.5 \\
\hline 238 & Oxic Live & 168 & 0.0399 & $1.80 \mathrm{E}-04$ & 10 & $1.35 \mathrm{E}-08$ & $1.887 \mathrm{E}-05$ & 0.1 & & & & & 20 & $6.70 \mathrm{E}-06$ & $1.34 \mathrm{E}-07$ & $1.34 \mathrm{E}-07$ & 0.1 \\
\hline 239 & Oxic Live & 168 & 0.0401 & $1.80 \mathrm{E}-04$ & 10 & $1.35 \mathrm{E}-08$ & $1.91 \mathrm{E}-05$ & 0.1 & & & & & 20 & & & & \\
\hline
\end{tabular}

${ }^{C}$ Includes $3 \mathrm{ml}$ supernatant and $17 \mathrm{ml} 0.6 \mathrm{~N} \mathrm{HCl}$.

${ }^{\mathrm{d}} \mathrm{Sum}$ of $\mathrm{Fe}(\mathrm{II})$ in $0.5 \mathrm{~N} \mathrm{HCl}$ extraction solution and dissolved $\mathrm{Fe}(\mathrm{II})$ that was removed when $7 \mathrm{ml}$ supernatant was removed.

${ }^{\mathrm{e}}$ Detection limit of $0.4 \mu \mathrm{M}$ was assumed after Washington et al. (Ref. 26). 

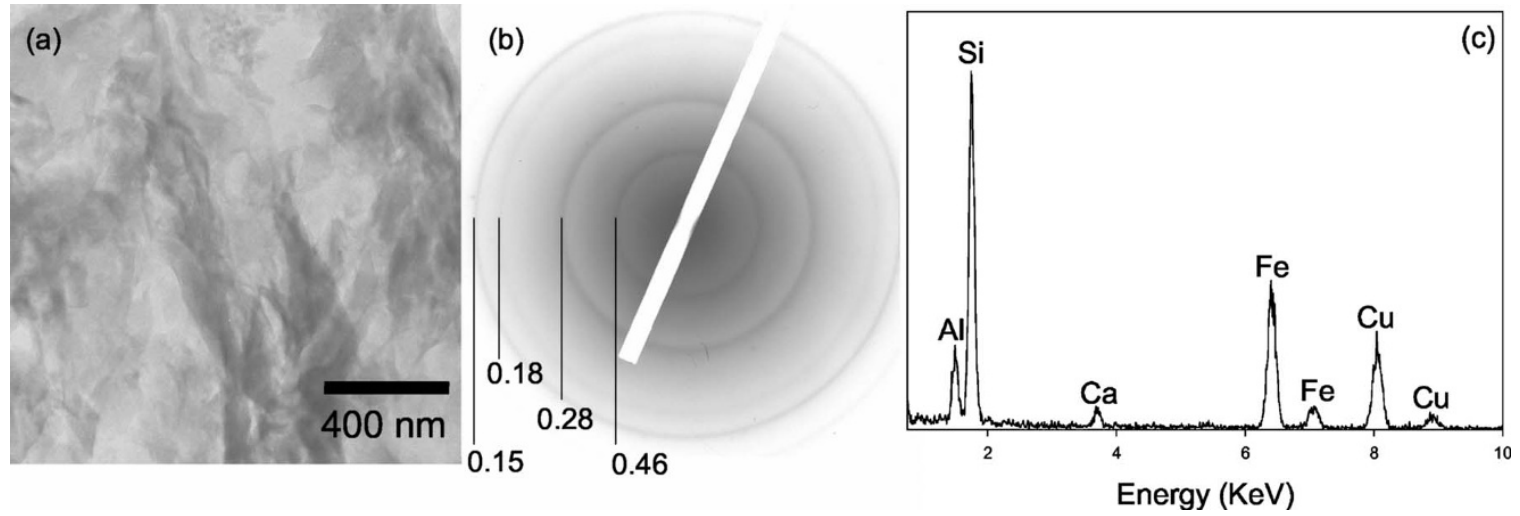

FIG. 3. (a) TEM bright field image of an NAu-1 aggregate suspended in 25\% M1 medium. The sample was embedded in hydrophilic resin, which was then cured and sliced into ultrathin sections. (b) SAED pattern of the aggregate, exhibiting well-defined smectite diffraction rings. The corresponding $d$-spacing values (nm) are indicated. (c) EDXS spectrum taken from the aggregate, showing that the aggregate is primarily composed of $\mathrm{Si}, \mathrm{Al}, \mathrm{Fe}$, and $\mathrm{Ca}$. Note that the $\mathrm{Cu}$ signals in this and all other EDXS spectra in this study are from the sample mounting material.
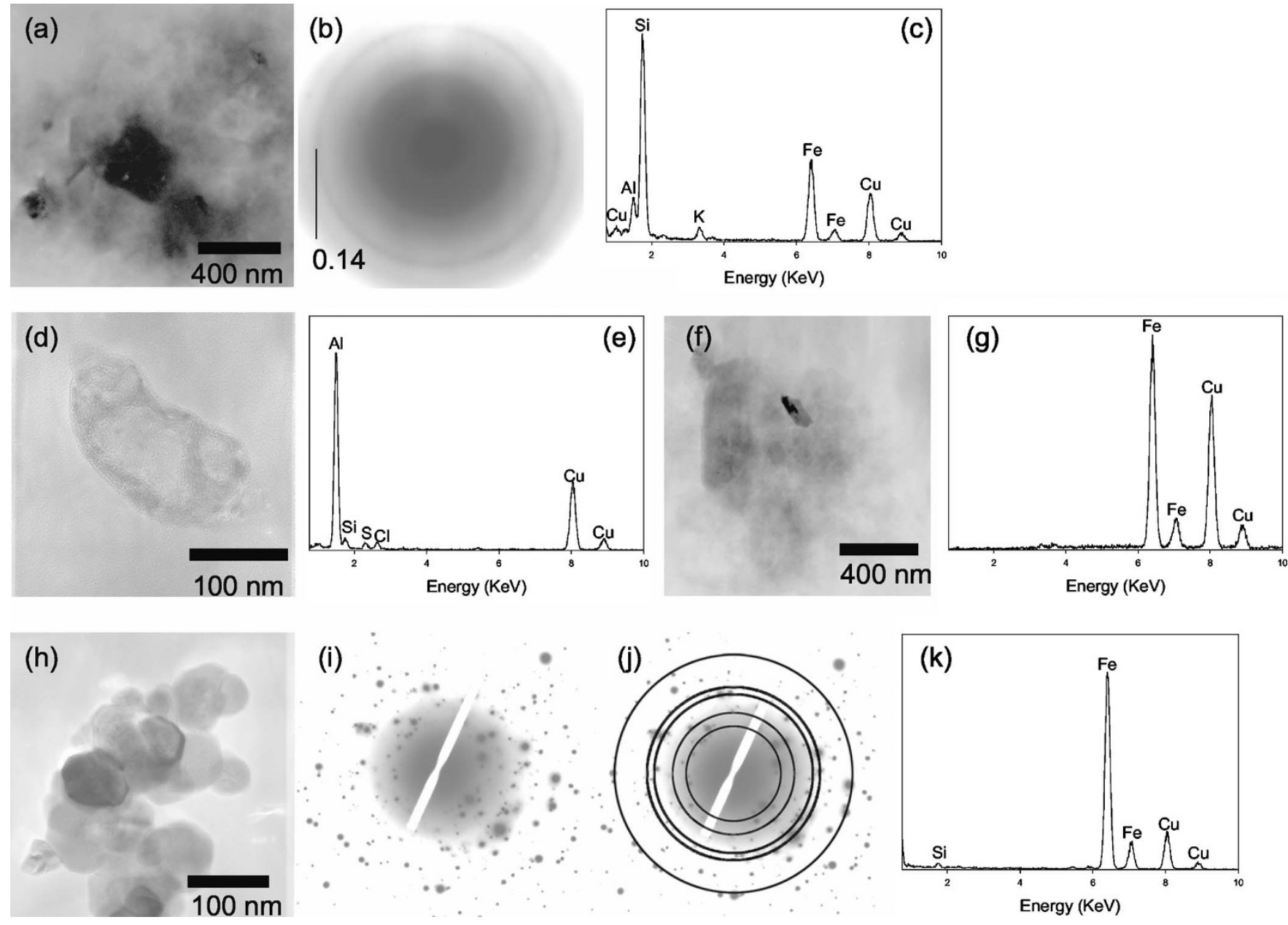

FIG. 4. (a) TEM bright field image of a poorly crystalline aggregate found in the product of 4 hours, anaerobic incubation with viable DIRB. (b) SAED pattern of the aggregate indicates that the particles in this aggregate are poorly crystalline. (c) EDXS spectrum of the aggregate shows that the aggregate is primarily composed of $\mathrm{Si}, \mathrm{Al}, \mathrm{Fe}$, and $\mathrm{K}$. (d) TEM bright field image of a bacterial cell found in the 24 hours, anaerobic incubation with viable DIRB. (e) EDXS spectrum of the bacterial cell reveals a strong Al signal, indicating that the cell is heavily encrusted with Al, perhaps due to adsorption. (f) TEM bright field image of a particulate organic matter (possibly an EPS) associated with an amorphous solid. (g) EDXS spectrum of the amorphous solid indicates that it is rich in Fe. (h) TEM bright field image of a cluster of nanosized grains with a hexagonal habit found in the 24 hours anaerobic incubation with viable DIRB. (i) SAED pattern for the cluster consists of a series of discrete diffraction spots. (j) The SAED pattern is overlaid with a set of expected powder diffraction rings for siderite (JCPDS Card 8-133). The diffraction rings correspond to the $d$-spacing values (and $h k l$ indices) of 3.59 (012), 2.79 (104), 2.13 (113), 1.96 (202), and 1.43 (214). (k) EDXS spectrum from this cluster shows that the cluster is composed predominantly of Fe. Note that the EDXS signals from light elements such as carbon and oxygen are not shown because they appear in the region with high background signals, and also they are abundant in the sample mounting material. 
ding material of choice for high-resolution microscopy work in which the structural preservation of organic materials associated with bacterial cells is important. For the preparation of sediments and colloidal suspension in nonmarine, low ionic strength aqueous environments, Nanoplast embedding yields high quality ultrathin sections free of extraction artifacts and salt precipitation with minimal handling disturbance to the structural integrity. ${ }^{39,42}$ Nanoplast has also been successfully used for the microstructural preservation of marine organoclay colloids (i.e., marine snow) and microbial communities associated with marine stromatolites without any salt precipitation visible under TEM or confocal microscopy. ${ }^{43-46}$ For our samples, we followed the preparation procedure detailed by Leppard and co-workers for the preparation of marine snow. ${ }^{43}$ The resin mixture was allowed to slowly replace interstitial water in a $40{ }^{\circ} \mathrm{C}$ oven for two days, and subsequently cured at $60{ }^{\circ} \mathrm{C}$ for two days. The Nanoplast-embedded sample was ultrathin-sectioned, and examined with JEOL3010 TEM (operated at $300 \mathrm{kV}$ ] with Noran energy-dispersive $\mathrm{x}$-ray spectroscopy (EDXS) and selected area electron diffraction (SAED).

\section{RESULTS AND DISCUSSION}

\section{Behavior of Fe}

Partitioning of Fe between solid and aqueous phases was determined for Experiment 2, along with the ratio of $\mathrm{Fe}(\mathrm{II})$ and $\mathrm{Fe}(\mathrm{III})$ in the dissolved fraction [Fig. 1 and Table I]. The results indicate that (i) the partitioning of $\mathrm{Fe}$ into aqueous phase increased with time during the seven days run in anaerobic viable cultures and anaerobic killed cultures; (ii) aqueous $\mathrm{Fe}$ increased immediately within 4 hours in the viable aerobic cultures and held steady for the reminder of seven days run; (iii) the majority of Fe in the dissolved fraction was in the oxidized form [i.e., Fe(III)] even in the anaerobic systems with viable DIRB; (iv) only up to $\sim 0.1 \%$ of total Fe was partitioned to the solution whereas $\sim 99.9 \%$ of Fe was associated with the solid phases even after seven days (Fig. 1); and (v) net reduction of Fe in the batch systems of Experiment 2 reached $4.5 \%$ after seven days in the anaerobic cultures with viable DIRB (Fig. 2).

In the flow-through systems of Experiment 1, very small amounts of $\mathrm{Fe}$ were partitioned into the aqueous effluent aliquots during the seven days run, and the cumulative total reached a mere $\sim 0.2 \%$ of the original Fe present in the solid starting material, $200 \mathrm{mg}$ of NAu-1 (data not shown).

Net reduction of $\mathrm{Fe}$ in the anaerobic, viable flow system of Experiment 1 reached $7.0( \pm 1.0) \%$ of the original $\mathrm{Fe}$ present in NAu-1 after seven days. Note this value is from the triplicate analysis of solids recovered from the miscibleflow reactor cell when the experiment was terminated after seven days. The amount of reduced Fe(II) present in the aqueous phase can be considered negligible because the aqueous partitioning of total Fe was very small.

The extent of reduction observed here (i.e., up to $\sim 4.5 \%$ in batch systems and $\sim 7 \%$ in flow-through system) is less than the numbers reported previously for the microbial reduction of SWa-1 nontronite (i.e., $\sim 30 \%-45 \%]^{6,17,21,22}$ which is crystallographically different from NAu-1: the octahedral sheets of SWa-1 contain more $\mathrm{Al}$ and $\mathrm{Mg}$ and less $\mathrm{Fe}(\mathrm{III})$ than those of NAu-1. ${ }^{29}$

The behavior of Fe alone might suggest a solid-state transformation of NAu-1 to a clay that contains $\mathrm{Fe}(\mathrm{II})$ rather than $\mathrm{Fe}(\mathrm{III})$, as very little $\mathrm{Fe}$ is detected in the aqueous phase. However, the TEM analysis reveals extensive solid phase alterations as discussed in the next section.

\section{Identification of solid products}

Figures 3(a)-3(c) shows a TEM image of an unaltered aggregate of NAu-1 [Fig. 3(a)], the associated SAED pattern [Fig. 3(b)], and EDXS profile [Fig. 3(c)]. The TEM image shows an aggregate of clay particles with wavy appearances typical of smectitic clays. ${ }^{47}$ The SAED pattern exhibits a typical smectite electron diffraction pattern. The EDXS spectrum indicates abundant $\mathrm{Si}$ along with $\mathrm{Al}, \mathrm{Fe}$, and $\mathrm{Ca}$.

Figures 4(a)-4(c) is a product of NAu-1 alteration after 4 hours in the batch anaerobic live culture. The particles appear very poorly crystalline in the bright-field image [Fig. 4(a)], which is corroborated by the SAED pattern [Fig. 4(b)] which is much more diffused than the diffractions of original NAu-1 [i.e., Fig. 3(b)]. The EDXS spectrum indicates its elemental composition to be still similar to the original $\mathrm{NAu}-1$ in terms of $\mathrm{Al}, \mathrm{Si}$, and $\mathrm{Fe}$. The $\mathrm{Ca}$ peak present in original NAu-1 has been replaced by the K peak, suggesting cation exchange with the aqueous medium which contains more $\mathrm{K}$ than $\mathrm{Ca}$ (see Table II). The occurrence of poorly
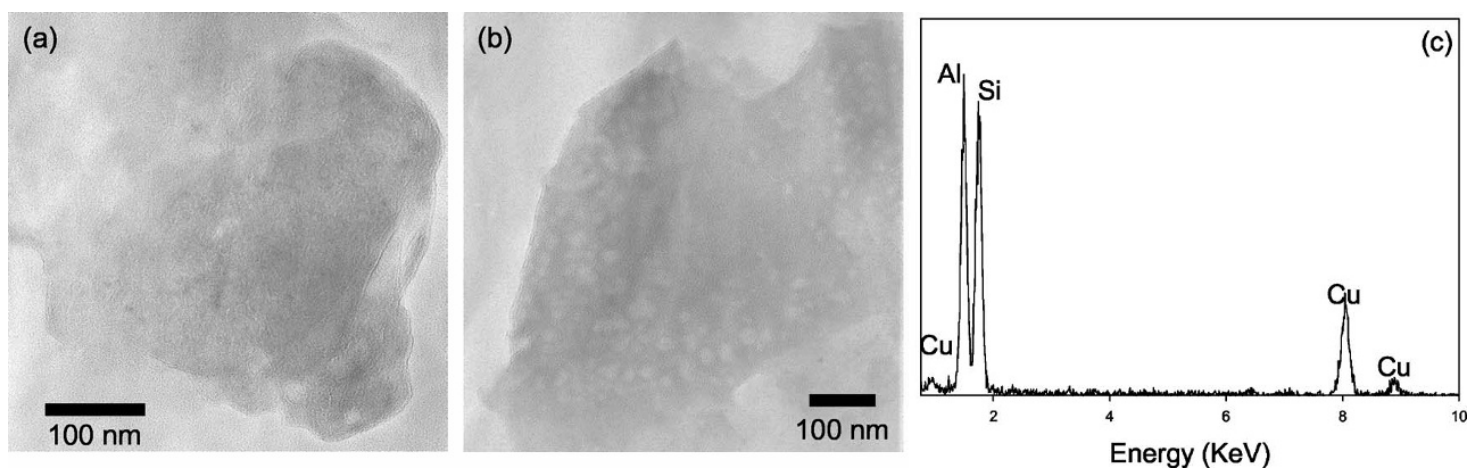

FIG. 5. (a) and (b) TEM bright field images of the discrete particles of amorphous aluminosilicate found in the 7 days, anaerobic incubation in the flow-through system with viable DIRB. (c) The EDXS spectra of these particles indicate that they are primarily composed of Al and Si, while other cations are undetected. 
TABLE II. Composition of full-strength M1 medium [after Myers and Nealson (Ref. 32) and Kostka and Nealson (Ref. 33)].

\begin{tabular}{cc}
\hline \hline Component & Concentration \\
\hline Lactate & $20 \mathrm{mM}$ \\
$\left(\mathrm{NH}_{4}\right)_{2} \mathrm{SO}_{4}$ & $9.0 \mathrm{mM}$ \\
$\mathrm{K}_{2} \mathrm{HPO}_{4}$ & $5.7 \mathrm{mM}$ \\
$\mathrm{KH}_{2} \mathrm{PO}_{4}$ & $3.3 \mathrm{mM}$ \\
$\mathrm{NaHCO}_{3}$ & $2.0 \mathrm{mM}$ \\
$\mathrm{MgSO}_{4}$ & $1.01 \mathrm{mM}$ \\
$\mathrm{CaCl}_{2}$ & $0.485 \mathrm{mM}$ \\
$\mathrm{Na}_{2} \mathrm{EDTA}$ & $67.2 \mu \mathrm{M}$ \\
$\mathrm{H}_{3} \mathrm{BO}_{3}$ & $56.6 \mu \mathrm{M}$ \\
$\mathrm{NaCl}$ & $10.0 \mu \mathrm{M}$ \\
$\mathrm{FeSO}_{4}$ & $5.4 \mu \mathrm{M}$ \\
$\mathrm{CoSO}_{4}$ & $5.0 \mu \mathrm{M}$ \\
$\left.\mathrm{Ni}_{\mathrm{NH}}\right)_{2}\left(\mathrm{SO}_{4}\right)_{2}$ & $5.0 \mu \mathrm{M}$ \\
$\mathrm{Na}_{2} \mathrm{MoO}_{4}$ & $3.87 \mu \mathrm{M}$ \\
$\mathrm{Na}_{2} \mathrm{SeO}_{4}$ & $1.5 \mu \mathrm{M}$ \\
$\mathrm{MnSO}_{4}$ & $1.26 \mu \mathrm{M}$ \\
$\mathrm{ZnSO}_{4}$ & $1.04 \mu \mathrm{M}$ \\
$\mathrm{CuSO}_{4}$ & $0.2 \mu \mathrm{M}$ \\
$\mathrm{Arginine}$ & $20 \mathrm{mg} \mathrm{L}$ \\
$\mathrm{Glutamate}^{-1}$ & $20 \mathrm{mg} \mathrm{L}$ \\
$\mathrm{Serine}^{-1}$ & $20 \mathrm{mg} \mathrm{L}$ \\
\hline \hline
\end{tabular}

crystalline smectite was widespread in the samples from 4 hours anaerobic live incubations whereas the extent of $\mathrm{Fe}$ reduction in those samples was only $0.1 \%-0.2 \%$ (see Fig. 2 and Table I). This suggests that NAu-1 alteration precedes microbial Fe reduction. The $24 \mathrm{~h}$ anaerobic live culture also contained bacterial cells in intimate association with $\mathrm{Al}$ [Figs. 4(d) and 4(e)]. Amorphous, Fe-rich precipitates were also found to be associated with particulate organic matter [likely extracellular polymer substances (EPS)] in the $4 \mathrm{~h}$ incubation product of an anaerobic, viable culture [Fig. 4(f)]. Trivalent cations such as $\mathrm{Al}$ and $\mathrm{Fe}(\mathrm{III})$ are electrostatically attracted to negatively charged bacteria surfaces and EPS, ${ }^{48}$ thus $\mathrm{Al}$ and $\mathrm{Fe}$ ions released due to NAu-1 alteration would be expected to become associated with bacterial cells and EPS, as observed in these images. In addition, siderite with the morphology similar to those formed by the DIRB reduction of amorphous ferric hydroxides ${ }^{49}$ was found in the anaerobic, live culture after $24 \mathrm{~h}$ of incubation [Figs. $4(\mathrm{~h})-4(\mathrm{k})]$.

After the seven days of anaerobic, live, flow-through experiments in which $\mathrm{Fe}(\mathrm{III})$ from NAu-1 was the only TEA, the products exhibited evidence of further alterations. Small, discrete domains of amorphous particles rich in $\mathrm{Al}$ and $\mathrm{Si}$ were observed [Figs. 5(a) and 5(b)]. The amorphous nature of these particles was confirmed by SAED (data not shown). EDXS analyses of these particles revealed that the relative ratio of $\mathrm{Al}$ to $\mathrm{Si}$ is greater than that of the original NAu-1 shown in Fig. 3(c). Some of the elements abundant in the original NAu-1 in octahedral sites as well as in interlayer spaces, namely $\mathrm{Fe}$ and $\mathrm{Ca}$, are absent in these amorphous aluminosilicate phases. The $\mathrm{Al} / \mathrm{Si}$ ratio of these particles and the absence of $\mathrm{Fe}$ and $\mathrm{Ca}$ make the chemical composition of these particles closer to that of kaolinite group clays (e.g., kaolinite and halloysite) than that of NAu-1. Transformation of low $\mathrm{Al} / \mathrm{Si}$ clays to poorly ordered aluminosilicates with near-unity $\mathrm{Al} / \mathrm{Si}$ ratio in the immediate vicinity of bacterial cells has been previously reported from weathered pyroclastic deposits, ${ }^{50}$ in experimental incubations of volcanic ash, ${ }^{51}$ in lake sediments enriched with metal contaminants, ${ }^{52}$ and in river sediments in association with fresh water biofilms. ${ }^{53-55}$ These previous authors have attributed the transformation to the three step process: (1) dissolution of primary minerals; (2) subsequent interaction between bacterial cell surfaces and dissolved cations; and (3) precipitation of poorly ordered aluminosilicate phases.

Alteration products were also found in aerobic batch systems in which DIRB respired $\mathrm{O}_{2}$ rather than $\mathrm{Fe}(\mathrm{III})$ from NAu-1. After seven days of aerobic, live, batch incubation, the samples contained poorly crystalline smectitic clays with $\mathrm{Si}, \mathrm{Al}$, and Fe [Figs. 6(a) and 6(b)]. Cation exchange in the aerobic sample was not as extensive as the cation exchange that occurred in the anaerobic batch sample, as the Ca peak was still visible [e.g., comparison between Figs. 4(c) and 6(b)]. The same seven days aerobic, live, batch incubation also included amorphous aluminosilicates with increased $\mathrm{Al} / \mathrm{Si}$ ratio similar to the ones shown in Fig. 5.

In addition to the above phases, amorphous $\mathrm{Si}$ globules with $\sim 50 \mathrm{~nm}$ diameter in close association with bacterial cells and the EPS were found in all systems that contained either viable or killed bacterial cells [Figs. 7(a) and 7(b)]. This is in agreement with previous studies that found cell surfaces or EPS to be the site of silica polymerization. ${ }^{56,57}$

In anaerobic batch systems with killed DIRB, amorphous $\mathrm{Fe}$ precipitates were found in close association with amorphous Si globules [Figs. 8(a) and 8(b)]. These systems contained nonviable cells of $S$. oneidensis along with any

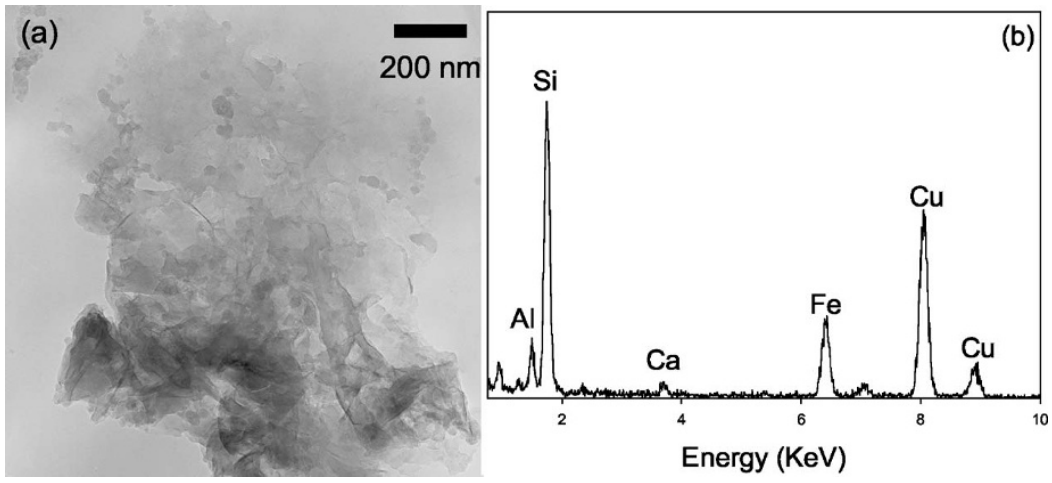

FIG. 6. (a) TEM bright field image of a cluster of poorly crystalline clay mineral particles found in the 7 days aerobic incubation. (b) EDXS spectrum of the aggregate shows that the elemental composition of these poorly crystalline particles is similar to that of NAu-1. 

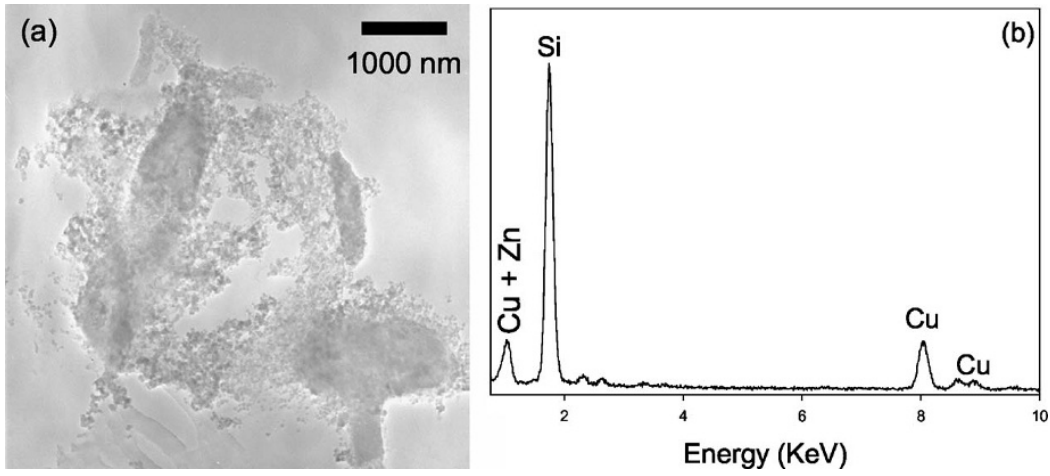

FIG. 7. (a) In all systems with either viable or killed DIRB, regardless of the $\mathrm{O}_{2}$ concentrations, we found small $(\sim 50 \mathrm{~nm})$ globules of amorphous $\mathrm{Si}$ encrusting bacterial cells and EPS, as shown in this TEM bright field image. (b) EDXS spectrum shows that the amorphous globules are rich in $\mathrm{Si}$. The $\mathrm{Zn}$ signal is from the sample mounting material.

biomolecules and EPS produced by the bacteria before the heat treatment.

In order to maintain mass balance, the secondary formation of Fe-poor phases such as those seen in Figs. 5(a), 5(b), and 7(a) must be accompanied by the formation of Fe-rich phases such as those found in Figs. 4(f), 4(h), and 8(a). In reducing (i.e., anaerobic live culture) systems, Fe(II) minerals such as siderite [e.g., Fig. 4(f)] are expected to precipitate. In the absence of microbial Fe(III) reduction, or if the rate of microbial $\mathrm{Fe}(\mathrm{III})$ reduction is less than the rate of NAu-1 alteration, Fe(III) may be incorporated into poorly crystalline, high-surface area $\mathrm{Fe}(\mathrm{III})$ precipitates, or it may be adsorbed onto other solid phases or negatively charged bacterial cells and EPS. ${ }^{58}$ The high reactivity of poorly crystalline $\mathrm{Fe}$ (III) precipitates with a large specific surface area toward microbial respiration has been quantitatively recognized. ${ }^{59}$ In addition, a small, but finite quantity of dissolved Fe(III) was detected in all of our experimental batch systems (Fig. 1). Thus, it is possible that Fe(III) incorporated into secondary phases, adsorbed onto the surfaces of secondary phases or bacterial cells, or dissolved Fe(III) species, rather than $\mathrm{Fe}(\mathrm{III})$ in the octahedral sheets of original NAu-1, is the primary TEA in our experimental systems.

These observations suggest that a portion of original NAu-1 present in each system, regardless of the $\mathrm{O}_{2}$ content or biological conditions, undergoes alteration and transforms to poorly crystalline smectite as well as authigenic phases in the aqueous medium used in our experimental systems. Poorly crystalline smectite was found in all systems (i.e., anaerobic live, anaerobic killed, and aerobic live). Amorphous aluminosilicates with increased $\mathrm{A} / \mathrm{Si}$ ratio were found in the anaerobic, live flow-through culture as well as in the seven days incubation of aerobic live culture. In reducing systems (i.e., anaerobic live cultures), siderite was also found. These observations indicate that microbial Fe(III) respiration is not a prerequisite for the NAu-1 alteration. NAu-1 alteration was observed in all systems including those in which $\mathrm{S}$. oneidensis respired $\mathrm{O}_{2}$, and those in which no viable cells were present. The secondary phases identified by TEM are summarized in Table III.

\section{Coupling between NAu-1 alteration and Fe reduction}

Brief ( 4 hours -7 days) incubations with viable as well as killed bacteria, with or without $\mathrm{O}_{2}$ as the primary TEA, resulted in clay aggregates that are much less crystalline than the original NAu-1. Secondary mineral phases such as amorphous aluminosilicates with increased $\mathrm{Al} / \mathrm{Si}$ ratio, and amorphous Si globules in close association with bacterial cells and EPS, were found in our experimental systems regardless of the availability of $\mathrm{O}_{2}$ as a TEA or the extent of microbial $\mathrm{Fe}(\mathrm{III})$ reduction. Meanwhile, although in small quantities, dissolved $\mathrm{Fe}(\mathrm{III})$ species were detected in all systems including the reducing systems (Fig. 1). These observations lead us to conclude that microbial $\mathrm{Fe}(\mathrm{III})$ reduction occurred after NAu-1 alteration or secondary mineral formation in our experimental systems.

In other words, these observations suggest that microbial reduction is not primarily of $\mathrm{Fe}(\mathrm{III})$ within the octahedral sheets of original $\mathrm{NAu}-1$, but of $\mathrm{Fe}(\mathrm{III})$ that is no longer a part of the original, well-crystallized NAu-1. It can be speculated that $\mathrm{Fe}$ (III) that is no longer associated with the octahedral sheets of well-crystallized NAu-1 would have been more readily available for microbial reduction than $\mathrm{Fe}(\mathrm{III})$ in the original NAu-1. In anaerobic systems with viable bacteria, these Fe(III) would be respired by DIRB and transformed

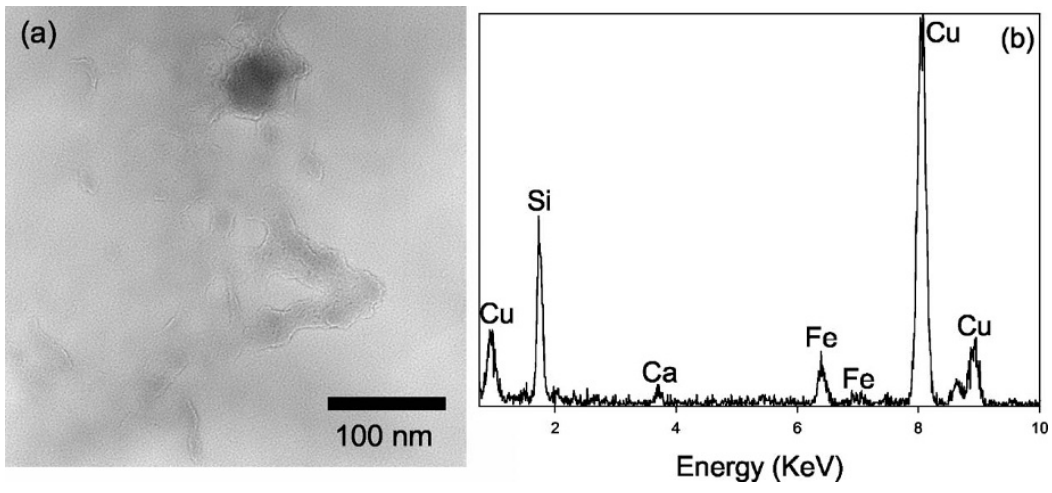

FIG. 8. (a) TEM bright field image of the amorphous Fe precipitate ( $\sim 50 \mathrm{~nm}$ dark grain near the top) associated with chained globules of amorphous $\mathrm{Si}$ found in the 7 days anaerobic system with killed DIRB. (b) EDXS spectrum indicates that this assemblage is rich is $\mathrm{Fe}$ and $\mathrm{Si}$, along with a small amount of $\mathrm{Ca}$. 
TABLE III. Summary of experimental products.

\begin{tabular}{|c|c|c|c|c|c|}
\hline & $\begin{array}{c}\text { Flow-through } \\
\text { Anaerobic } \\
\text { Viable } \\
\text { DIRB } \\
7 \text { days }\end{array}$ & $\begin{array}{c}\text { Batch } \\
\text { Anaerobic } \\
\text { Viable } \\
\text { DIRB } \\
4 \text { hours }\end{array}$ & $\begin{array}{c}\text { Batch } \\
\text { Anaerobic } \\
\text { Viable } \\
\text { DIRB } \\
7 \text { days }\end{array}$ & $\begin{array}{c}\text { Batch } \\
\text { Anaerobic } \\
\text { Killed } \\
\text { DIRB } \\
7 \text { days }\end{array}$ & $\begin{array}{c}\text { Batch } \\
\text { Aerobic } \\
\text { Viable } \\
\text { DIRB } \\
7 \text { days }\end{array}$ \\
\hline Primary TEA & $\mathrm{Fe}(\mathrm{III})$ & $\mathrm{Fe}(\mathrm{III})$ & $\mathrm{Fe}(\mathrm{III})$ & N/A & $\mathrm{O}_{2}$ \\
\hline Extent of $\mathrm{Fe}$ reduction & $7 \% \pm 1 \%$ & $0.1 \%-0.2 \%$ & $4.4 \%-4.6 \%$ & $\begin{array}{l}0.3- \\
1.2 \%\end{array}$ & $\begin{array}{l}0.1- \\
0.5 \%\end{array}$ \\
\hline \multicolumn{6}{|l|}{ Phases present } \\
\hline $\begin{array}{l}\text { Poorly crystalline } \\
\text { smectite }\end{array}$ & Not found & Yes & Yes & Yes & Yes \\
\hline $\begin{array}{l}\text { Amorphous } \\
\text { aluminosilicate with } \\
\text { increased } \mathrm{Al} / \mathrm{Si}\end{array}$ & Yes & Not found & Not found & Not found & Yes \\
\hline Amorphous Si & Yes & Yes & Yes & Yes & Yes \\
\hline
\end{tabular}

to $\mathrm{Fe}(\mathrm{II})$. The majority of $\mathrm{Fe}(\mathrm{II})$ would then partition into solid phases as Fe(II) minerals and as adsorbed species on EPS and bacterial cells, since little dissolved Fe(II) was detected in the experimental systems.

In summary, microbial reduction of NAu-1 in our laboratory systems proceeded through (1) alteration of NAu-1 to poorly crystalline clays, as well as to Fe-poor aluminosilicates which are mass-balanced by the formation of Fe(III) precipitates or dissolved Fe(III) species; and (2) subsequent microbial respiration of $\mathrm{Fe}(\mathrm{III})$ that is not associated with the octahedral sheets of well-crystallized NAu-1. With or without the presence of microbial Fe(III) reduction, the alteration continued to yield such secondary phases as amorphous aluminosilicates with increased $\mathrm{Al} / \mathrm{Si}$ ratio, amorphous Si globules in close association with bacterial cells and EPS, and amorphous Fe precipitates. Our laboratory study suggests that, in nature, microbial respiration of $\mathrm{Fe}(\mathrm{III})$ in clay minerals of anaerobic soils and sediments is initiated by the alteration of clay minerals followed by microbial respiration of $\mathrm{Fe}(\mathrm{III})$ that is no longer in the octahedral sheets of wellcrystallized clays. This suggested mechanism would make the transfer of electrons through tetrahedral layers of well crystallized smectite unnecessary.

\section{ACKNOWLEDGMENTS}

This study was funded by ONR/NRL Core 6.1 funding (PE\#0601153N). One of the authors (S.E.O) was supported through the National Research Council at NRL. ICP analysis was conducted by J. Kolberg at Applied Geo Technologies, Inc. (Stennis Space Center, Mississippi). NRL Electron Microscopy Facility (Stennis Space Center, Mississippi) provided support for the TEM analysis. The authors would like to thank S. Newell for assistance with the SYBR Green fluorescence bacterial counting. NRL Contribution No. JA/743004- 15 .

${ }^{1}$ P. N. Froelich, G. P. Klinkhammer, M. L. Bender et al., Geochim. Cosmochim. Acta 43(7), 1075 (1979).

${ }^{2}$ D. E. Canfield, B. B. Jorgensen, H. Fossing et al., Mar. Geol. 113(1-2), 27 (1993).

${ }^{3}$ E. E. Roden and R. G. Wetzel, Limnol. Oceanogr. 41(8), 1733 (1996).

${ }^{4}$ B. Thamdrup and D. E. Canfield, Limnol. Oceanogr. 41, 1629 (1996).

${ }^{5}$ J. E. Kostka, B. Gribsholt, E. Petrie et al., Limnol. Oceanogr. 47(1), 230
(2002).

${ }^{6}$ J. E. Kostka, J. W. Stucki, K. H. Nealson et al., Clays Clay Miner. 44(4), 522 (1996).

${ }^{7}$ J. Kim, Y. Furukawa, H. L. Dong et al., Clays Clay Miner. (in press).

${ }^{8}$ D. E. Canfield, Geochim. Cosmochim. Acta 53(3), 619 (1989).

${ }^{9}$ D. E. Canfield, B. Thamdrup, and J. W. Hansen, Geochim. Cosmochim. Acta 57(16), 3867 (1993).

${ }^{10}$ R. Raiswell and D. E. Canfield, Am. J. Sci. 298(3), 219 (1998).

${ }^{11}$ K. L. Lowe, T. J. Dichristina, A. N. Roychoudhury et al., Geomicrobiol. J. 17(2), 163 (2000).

${ }^{12}$ C. M. Koretsky, C. M. Moore, K. L. Lowe et al., Biogeochemistry 64(2), 179 (2003).

${ }^{13}$ Y. Furukawa, A. C. Smith, J. E. Kostka et al., Limnol. Oceanogr. 49(6), 2058 (2004).

${ }^{14}$ C. van der Zee, D. R. Roberts, D. G. Rancourt et al., Geology 31(11), 993 (2003).

${ }^{15}$ J. Wu, C. B. Roth, and P. F. Low, Soil Sci. Soc. Am. J. 52(1), 295 (1988).

${ }^{16}$ J. W. Stucki, P. Komadel, and H. T. Wilkinson, Soil Sci. Soc. Am. J. 51(6), 1663 (1987).

${ }^{17}$ H. L. Dong, J. E. Kostka, and J. Kim, Clays Clay Miner. 51(5), 502 (2003).

${ }^{18}$ J. W. Kim, Y. Furukawa, T. L. Daulton et al., Clays Clay Miner. 51(4), 382 (2003).

${ }^{19}$ H. L. Dong, R. K. Kukkadapu, J. K. Fredrickson et al., Environ. Sci. Technol. 37(7), 1268 (2003).

${ }^{20}$ J. E. Kostka, D. D. Dalton, H. Skelton et al., Appl. Environ. Microbiol. 68(12), 6256 (2002).

${ }^{21}$ J. E. Kostka, E. Haefele, R. Viehweger et al., Environ. Sci. Technol. 33(18), 3127 (1999).

${ }^{22}$ J. E. Kostka, J. Wu, K. H. Nealson et al., Geochim. Cosmochim. Acta 63(22), 3705 (1999).

${ }^{23}$ J. Kim, H. L. Dong, J. Seabaugh et al., Science 303(5659), 830 (2004).

${ }^{24}$ D. R. Lovley, D. E. Holmes, and K. P. Nevin, Adv. Microb. Physiol. 49, 219 (2004).

${ }^{25}$ Y. S. Luu and J. A. Ramsay, World J. Microbiol. Biotechnol. 19(2), 215 (2003).

${ }^{26}$ K. P. Nevin and D. R. Lovley, Geomicrobiol. J. 19(2), 141 (2002).

${ }^{27}$ J. F. Heidelberg, I. T. Paulsen, K. E. Nelson et al., Nat. Biotechnol. 20(11), 1118 (2002).

${ }^{28}$ C. R. Myers and J. M. Myers, J. Bacteriol. 174(11), 3429 (1992).

${ }^{29}$ W. P. Gates, P. G. Slade, A. Manceau et al., Clays Clay Miner. 50(2), 223 (2002).

${ }^{30}$ K. M. Rosso and E. S. Ilton, J. Chem. Phys. 119(17), 9207 (2003).

${ }^{31}$ J. L. Keeling, M. D. Raven, and W. P. Gates, Clays Clay Miner. 48(5), 537 (2000)

${ }^{32}$ C. R. Myers and K. H. Nealson, Science 240, 1319 (1988).

${ }^{33}$ J. E. Kostka and K. H. Nealson, in Techniques in Microbial Ecology, edited by R. S. Burlage (Oxford University Press, Oxford, 1998), p. 58.

${ }^{34}$ J. Skeidsvoll and P. M. Ueland, Anal. Biochem. 231(2), 359 (1995).

${ }^{35}$ E. Viollier, P. W. Inglett, K. Hunter et al., Appl. Geochem. 15(6), 785 (2000).

${ }^{36}$ J. W. Washington, D. M. Endale, L. P. Samarkina et al., Geochim. Cosmochim. Acta 68(23), 4831 (2004). 
${ }^{37}$ J. E. Kostka and K. H. Nealson, Environ. Sci. Technol. 29(10), 2535 (1995).

${ }^{38}$ C. Mondi, K. Leifer, D. Mavrocordatos et al., J. Microsc. (Paris) 207, 180 (2002).

${ }^{39}$ D. Perret, G. G. Leppard, M. Muller et al., Water Res. 25(11), 1333 (1991).

${ }^{40}$ K. J. Wilkinson, E. Balnois, G. G. Leppard et al., Colloids Surf., A $\mathbf{1 5 5}(2-$ 3), 287 (1999).

${ }^{41}$ S. M. Webb, G. G. Leppard, and J. F. Gaillard, Environ. Sci. Technol. 34(10), 1926 (2000).

${ }^{42}$ C. H. Swartz, A. L. Ulery, and P. M. Gschwend, Geochim. Cosmochim. Acta 61(4), 707 (1997).

${ }^{43}$ G. G. Leppard, A. Heissenberger, and G. J. Herndl, Mar. Ecol.: Prog. Ser. 135(1-3), 289 (1996).

${ }^{44}$ A. Heissenberger, G. G. Leppard, and G. J. Herndl, Mar. Ecol.: Prog. Ser. 135(1-3), 299 (1996).

${ }^{45}$ A. W. Decho and T. Kawaguchi, BioTechniques 27(6), 1246 (1999).

${ }^{46}$ T. Kawaguchi and A. W. Decho, Marine Biotechnology 4(2), 127 (2002).

${ }^{47}$ R. H. Bennett, N. R. O'Brien, and M. H. Hulbert, in Microstructure of Fine-Grained Sediments, edited by R. H. Bennett, W. R. Bryant, and M. H. Hulbert (Springer-Verlag, New York, 1990), p. 5.
${ }^{48}$ J. B. Fein, C. J. Daughney, N. Yee et al., Geochim. Cosmochim. Acta 61(16), 3319 (1997).

${ }^{49}$ J. K. Fredrickson, J. M. Zachara, D. W. Kennedy et al., Geochim. Cosmochim. Acta 62(19-20), 3239 (1998).

${ }^{50}$ M. Kawano and K. Tomita, Clays Clay Miner. 50(1), 99 (2002).

${ }^{51}$ M. Kawano and K. Tomita, Am. Mineral. 86(4), 400 (2001).

${ }^{52}$ F. G. Ferris, W. S. Fyfe, and T. J. Beveridge, Chem. Geol. 63(3-4), 225 (1987).

${ }^{53}$ K. O. Konhauser, Earth-Sci. Rev. 43(3-4), 91 (1998)

${ }^{54}$ K. O. Konhauser, S. Schultzelam, F. G. Ferris et al., Appl. Environ. Microbiol. 60(2), 549 (1994).

${ }^{55}$ K. O. Konhauser, W. S. Fyfe, F. G. Ferris et al., Geology 21(12), 1103 (1993).

${ }^{56}$ N. Yee, V. R. Phoenix, K. O. Konhauser et al., Chem. Geol. 199(1-2), 83 (2003).

${ }^{57}$ L. G. Benning, V. R. Phoenix, N. Yee et al., Geochim. Cosmochim. Acta 68(4), 729 (2004).

${ }^{58}$ S. Glasauer, S. Langley, and T. J. Beveridge, Appl. Environ. Microbiol. 67(12), 5544 (2001).

${ }^{59}$ E. E. Roden, Environ. Sci. Technol. 37(7), 1319 (2003). 